\title{
HEAVY METALS CONCENTRATION IN SOME FISH TISSUES FROM SOUTH MEDITERRANEAN WATERS, EGYPT
}

\author{
Ahmed El Nemr, Amany El-Sikaily and Azza Khaled \\ Environmental Division, National Institute of Oceanography and \\ Fisheries, Kayet Bay, Alexandria, Egypt
}

Keywords: fish, heavy metals, south Mediterranean, Lake Edku, Egypt

\begin{abstract}
T he concentrations of nine heavy metals $(\mathrm{Cd}, \mathrm{Co}, \mathrm{Cu}, \mathrm{Fe}, \mathrm{Hg}, \mathrm{Mn}$, $\mathrm{Ni}, \mathrm{Pd}$ and $\mathrm{Zn}$ ) were determined in five common fish namely: Sigana-Batata (Siganius rivulatus), Bouri (Mugil capito), and Balamita bed (Scomber unicolor) from the open sea, facing to Lake Edku, and Bolti Akhdar (Tilapia zillii) and Karmout (Clarias lazera) from Lake Edku. Three metals ( $\mathrm{Co}, \mathrm{Ni}$ and $\mathrm{Pd}$ ) were not yet detected in the studied fish species during the four seasons. The average concentrations of the other heavy metals analyzed exhibited the following decreasing order: $\mathrm{Fe}>\mathrm{Zn}>\mathrm{Mn}>\mathrm{Cd}>\mathrm{Cu}>\mathrm{Hg}$. The concentrations of $\mathrm{Cu}$ and $\mathrm{Zn}$ were lower than the Effect Range-Low (ERL) for all studied fish, while the other metals ( $\mathrm{Fe}, \mathrm{Mn}, \mathrm{Cd}$ and $\mathrm{Hg}$ ) were ranging from over the ERL and under the Effect Range-Median (ERM). These results suggest that the fish collected from open sea and Lake Edku might be considered relatively unpolluted with heavy metals. The metal pollution index (MPI) for most studied fish fluctuated between the calculated MPI for ERL and ERM. However, MPI recorded for summer showed the highest value over other seasons in the studied fish samples.
\end{abstract}

\section{INTRODUCTION}

Estuaries and coastal zones, particularly near large population centers, are of concern as they receive the largest discharges of chemical contamination due to source proximity. Confined bays and brackish Lakes are often the most ecologicaliy vulnerable and sensitive area. Toxic compounds can affect productivity, reproduction and survival of marine organisms and can be hazardous to human health. Coastal monitoring programs are valuable for assessing the 
current state of coastal environments, for determining trends in contaminants over space and time, and for identifying potential sources of contamination to prevent future problems.

Heavy metals, which are important pollutants in coastal waters, represent potential toxic substances associated with run-off. In the water column, they are known to be mainly associated with sediments and suspended particulate organic matter (Saouter et al., 1993). Metals contaminants can enter the environment in excess amounts from industrial and mining effluents, from the combustion of fossil fuels, discharge of sewage and sewage sludge; also from fertilizer and pesticide residues (Forstner and Wittmann 1979). Pathways for metal input to the marine environment include transport via rivers and streams, direct discharge and atmospheric fallout are well known. Over a few decades, there has been growing interest to determine heavy metal levels in the marine environment and attention was drawn to find out concentration level of public food supplies particularly fish. Therefore, metal body loads of aquatic biota are often measured and used to evaluate ecological risks and potential sublethal effects (Bryan et al., 1980 \& 1985; Phillips, 1980 \& 1990; Phillips and Rainbow, 1993; Rainbow, 1995; Kalay \& Canli, 1999).

The aim of this study is to determine heavy metal concentrations ( $\mathrm{Cd}, \mathrm{Co}, \mathrm{Cu}, \mathrm{Fe}, \mathrm{Hg}, \mathrm{Mn}, \mathrm{Ni}, \mathrm{Pb}$ and $\mathrm{Zn}$ ) in the muscle of fishes namely: Sigana-Batata (Siganus rivulatus), Bouri (Mugil capito), and Balamita bed (Scomber unicolor) from the open sea facing to Lake Edku and Bolti Akhdar (Tilapia zillii) and Armout (Clarias lazera) from Lake Edku, South Mediterranean Sea, Egypt (Figure 1). These fish species are very common food items for Egyptians and live in different ecological habitats and different feeding behavior (Table 1).

\section{MATERIAL AND METHODS}

Fish specimens of Sigana-Batata (Siganus rivulatus), Bouri (Mugil capito), Bolti Akhdar (Tilapia zillii), Armout (Clarias lazera) and Balamita bed (Scomber unicolor) were collected seasonally from autumn 2001 to summer 2002 from the South Mediterranean Sea and Lake Edku, by local fishermen. Ten fish were obtained from each species and were packed in ice and brought to the laboratory on the same day. Tissues of the examined fish were dissected, using clean equipment and put in petridishes and transferred into an oven set to $50{ }^{\circ} \mathrm{C}$ to dry. Drying continued until all the wet tissues reached to a 
constant weight. Dry tissue samples (triplicate each $0.2 \mathrm{~g}$ ) were put into digestion flasks followed by addition of $5 \mathrm{ml}$ nitric acid (Merck), $2 \mathrm{ml}$ perchloric acid and heated at $90^{\circ} \mathrm{C}$ until all the materials were dissolved. After digestion, the digested samples were diluted with deionized water, filtered and completed, using deionized water to 10 $\mathrm{ml}$. The resulting solutions were analyzed, using flame atomic absorption spectrophotometer (Perkin Elmer, Model 2380). The results were expressed in $\mathrm{mg} \mathrm{kg}^{-1}$ dry wt. (UNEP/FAO/IAEA/IOC, 1984). Metal concentrations are reported on dry weight basis, rather than wet weight to provide a more accurate measure of metal load, since water content in biota varies with species, age and condition.

Reagents of analytical grade were utilized for the blanks and calibration curves. Precision was checked against standard rëference material provided by the National Research Council of Canada (DORM-1 for dogfish) and was within the range of certified values with $96 \%$ recovery for all metals studied.

The absorption wavelength and detection limits were as follows: $228.8 \mathrm{~nm}$ and $0.06 \mathrm{mg} \mathrm{kg}^{-1}$ for $\mathrm{Cd} ; 240.7 \mathrm{~nm}$ and $0.05 \mathrm{mg}$ $\mathrm{kg}^{-1}$ for $\mathrm{Co} ; 324.7 \mathrm{~nm}$ and $0.06 \mathrm{mg} \mathrm{kg}^{-1}$ for $\mathrm{Cu} ; 248.3 \mathrm{~nm}$ and $0.8 \mathrm{mg}$ $\mathrm{kg}^{-1}$ for $\mathrm{Fe} ; 279.5 \mathrm{~nm}$ and $0.7 \mathrm{mg} \mathrm{kg}^{-1}$ for $\mathrm{Mn} ; 232.0 \mathrm{~nm}$ and $0.09 \mathrm{mg}$ $\mathrm{kg}^{-1}$ for $\mathrm{Ni} ; 217.0 \mathrm{~nm}$ and $0.8 \mathrm{mg} \mathrm{kg}^{-1}$ for $\mathrm{Pb} ; 213.9 \mathrm{~nm}$ and $0.7 \mathrm{mg}$ $\mathrm{kg}^{-1}$ for $\mathrm{Zn}$, respectively.

Mercury analysis was conducted, using cold vapor atomic absorption (SOLAAR 32). In which $0.2 \mathrm{~g}$ of the homogenized dry sample was weighed accurately into a previously pre-cleaned Teflon vial, $5 \mathrm{mI}$ of $\mathrm{HNO}_{3}$ and $2 \mathrm{ml}$ of perchloric acid were added and the mixture was heated at $50{ }^{\circ} \mathrm{C}$, until all the materials were dissolved. After cooling to room temperature, the volume was diluted, by using bi-distilled water, filtered and completed to $25 \mathrm{ml}$; then subjected to $\mathrm{Hg}$-determination with triplicate analysis (UNEP/IAEA 1984). To evaluate the accuracy and precision of the analytical methodology, reference material DORM-2 (provided by EIMP-IAEA) was run parallel with the samples. The recovery rate was $96 \%$ for total $\mathrm{Hg}$. A check standard and blank were run after every seven samples. Detection limit for $\mathrm{Hg}$ was $0.008 \mathrm{mg} \mathrm{kg}^{-1}$. All calculations were carried out on a Microsoft Excel program for Win XP 2002. 


\section{RESULTS AND DISCUSSION}

The results of heavy metals in the different fish species collected during the four seasons from the open sea and Lake Edku, south Mediterranean Sea are presented in Table 2. Heavy metal concentrations ranged between 0.44 to 1.86 for $\mathrm{Cu}, 21.01$ to 49.0 for $\mathrm{Zn}, 16.14$ to 33.58 for $\mathrm{Mn}, 143.34$ to 2439.16 for $\mathrm{Fe}, 0.92$ to 3.19 for $\mathrm{Cd}$ and 0.05 to $1.61 \mathrm{mg} \mathrm{kg}^{-1}$ dry wt. for $\mathrm{Hg}$, while $\mathrm{Co}, \mathrm{Ni}$ and $\mathrm{Pd}$ were not detected in all studied samples.

Cadmium concentrations in fish tissues were elevated with some variations between species, where the highest concentrations were $3.19 \pm 0.53$ in autumn and $2.53 \pm 0.42$ in Spring in Clarias lazera, while $\mathrm{Cd}$ was not detected in winter. The concentrations of $\mathrm{Cd}$ were higher than ERL (1.2 $\mathrm{mg} \mathrm{kg}^{-1}$ ) and lower than ERM (9.6 $\mathrm{mg} \mathrm{kg}^{-1}$ ) for all studied samples except for Siganus rivulatus collected in autumn and Clarias collected in winter. The concentrations of $\mathrm{Cd}$ recorded in this study were lower than these recorded from Lake Edku (Table 3) (Emara, 1982) and about two to four times more than these from Lake Mariut (Saad et al. 1981), but lesser than these reported for the North Pacific, USA (Miao et al. 2001). However, this study showed lower Cd content in Lake Edku during the last twenty years. Kilgour (1991) indicated that fish with a close relationship with sediment, show relatively high body concentration of $\mathrm{Cd}$, although uptake from water higher than uptake from sediment for fishes which do not burrow.

Mercury was greatly elevated than ERL $\left(0.15 \mathrm{mg} \mathrm{kg}^{-1}\right)$ for most of the studied samples except for Mugil capito, which recorded low concentration than ERL, while, Tilapia zillii recorded $\mathrm{Hg}$ concentrations over ERM $\left(0.71 \mathrm{mg} \mathrm{kg}^{-1}\right)$ for samples collected in summer and autumn. Meanwhile, Clarias lazera recorded slightly elevated $\mathrm{Hg}$ than ERM in winter samples. This may be due to industrial and municipal wastes, which come from different factories constructed near Abu-Qir, (e.g. El-Ahlia-paper factory, Rakta paper factory, Abu-Qir fertilizers factory) beside the Electric Power Station and El-Amria (Abu-Qir) Drain.

The concentrations of iron were fluctuated between $143.34 \pm$ 22.68 to $2439 \pm 1387 \mathrm{mg} \mathrm{kg}^{-1}$. The highest concentration of Fe was present in Balamita (Scomber unicolor) during summer and the lowest was recorded for Tilapia zillii in autumn. However, summer samples recorded higher iron concentrations for all studied samples, while the lowest iron concentrations recorded for samples collected 


\section{HEAVY METALS CONCENTRATION IN SOME FISH 159 TISSUES FROM SOUTH MEDITERRANEAN WATERS, EGYPT}

from open sea and Lake Edku were reported in winter and autumn, respectively.

Copper concentrations exhibited low values for all studied samples collected from both open sea and Lake Edku ranging between $0.44 \pm 0.09$ and $1.86 \pm 0.14 \mathrm{mg} \mathrm{kg}^{-1}$, which are much lower than ERI ( $34 \mathrm{mg} \mathrm{kg}^{-1}$ ). The $\mathrm{Cu}$ concentrations recorded in this study were much lower than that recorded by Shakweer (1993) for Lake Edku and one third of that recorded by El-Moselhy (1996) for Alexandria and Red Sea (Table 3), which may indicate a remarkable decrease in $\mathrm{Cu}$ content during the last few years for Lake Edku.

Manganese concentrations in fish tissues varied between $16.31 \pm 0.98$ and $33.58 \pm 0.74 \mathrm{mg} \mathrm{kg}^{-1}$. The higher concentrations of $\mathrm{Mn}$ were recorded in summer samples collected from the open sea and in spring samples from Lake Edku. Zn concentrations fluctuated between $21.01 \pm 2.38$ and $49 \pm 4.33 \mathrm{mg} \mathrm{kg}^{-1}$ which were much lower than ERL (150 $\left.\mathrm{mg} \mathrm{kg}^{-1}\right)$. "However, $\mathrm{Zn}$ and $\mathrm{Fe}$ may vary between different fish species as a result of their biological needs (Quazi et al., 1995). It is generally agreed that heavy metal uptake occurs mainly from water, food and sediment, however, effectiveness of metal uptake from these sources may differ in relation to ecological needs, metabolism of fish contamination gradient of water, food and sediments as well as other factors such as temperature (Health, 1987; Langston, 1990; Roesijadi and Robinson, 1994). Canli and Furness (1995) also showed that tissue distribution of metals in the Norway Lobster, Nephross navegicus differed significantly owing to the uptake from food and from seawater.

The significant correlation (at $\mathrm{p}<0.05$ ) between metal concentrations in fish tissues were studied between seasons and species. The results of summer, autumn and spring samples showed no correlation between the metal concentrations, while in winter samples, a positive correlation was noted between $\mathrm{Cu}$ and $\mathrm{Zn}(\mathrm{r}=$ $0.89, \mathrm{p}=0.04)$ and a negative correlation between $\mathrm{Fe}$ and $\mathrm{Zn}(\mathrm{r}=-$ $0.92, p=0.02$ ). The correlations of heavy metal concentrations for each species separately recorded no correlation for Mugil capito and Tilapia zillii, while Siganus rivulatus showed a negative correlation between $\mathrm{Cd}$ and $\mathrm{Zn}(\mathrm{r}=-0.98, \mathrm{p}=0.02)$ and a positive correlation between $\mathrm{Cu}$ and $\mathrm{Zn}(\mathrm{r}=0.96, \mathrm{p}=0.03)$, Scomber unicolor showed only a positive correlation between $\mathrm{Cd}$ and $\mathrm{Zn}(\mathrm{r}=0.999, \mathrm{p}=0.007)$, and Clarias lazera showed a negative correlation between $\mathrm{Mn}$ and $\mathrm{Fe}$ $(r=-0.98, p=0.01)$. However, the correlation between the 113 
parameters showed only a moderate correlation between $\mathrm{Fe}$ and $\mathrm{Hg}$ ( $\mathrm{r}$ $=0.56, \mathrm{p}=0.015$ ).

The principle component factor analysis $\left(\mathrm{PCF} \beta_{k}\right)$ was preformed on the 113 heavy metals values using Varimax Normalized. The PCF analysis, at its simplest, can be regarded simply as an ordination technique, for reducing multivariate data into fewer dimensions. PCF analysis transforms an original set of $\mathrm{N}$ variables into a net set of $\mathrm{N}$ principle components. The transformation is such that the first and second components almost invariably account for a far proportion of the total value (Davis et al., 1973; Hopke, 1983; Meglen, 1992). Figure 2 shows the spatial distribution of the different elements with respect to both factor 1 and factor 2 which explain $89.99 \%$ of the total variance with data variations of $33.11 \%$ for factor 1 and $56.81 \%$ for factor 2. Both factor 1 and 2 lie on their positive side $\mathrm{Cd}, \mathrm{Mn}, \mathrm{Fe}$ and $\mathrm{Zn}$. On the other hand, factor 2 loads $\mathrm{Hg}$ on its positive side, where its loads lie on the negative side of factor 1 with a high (0.92) and low (-0.18) values, respectively. The statistical analysis indicates that the distribution pattern of $\mathrm{Hg}$ (Factor 2 ) is very different from that of the other metals. Point sources as they exist for the other analysed heavy metals do not exist or are of subordinate importance for this metal. The clustering of the other metals $(\mathrm{Cd}, \mathrm{Cu}$, $\mathrm{Mn}$ and $\mathrm{Zn}$ ) together may indicate the syngestic sources of these metals.

The overall metal contents of fish tissues at the sites investigated in this study were compared, using the metal pollution index (MPI) calculated with the formula (Usero et al., 1996 and 1997):

$\mathrm{MPI}=(\mathrm{Cd} \times \mathrm{Cu} \times \mathrm{Fe} \times \mathrm{Hg} \times \mathrm{Mn} \times \mathrm{Zn})^{1 / 6}$

MPI ratios ranged between 0.92 for Tilapia zillii in autumn samples to 3.72 for Scomber unicolor in summer samples. Moreover, MPI were higher in summer samples for all species (Table 2). However, heavy metal concentrations recorded in this study were lower than the maximum acceptable limits shown in Table 4, indicating that, the five fish species examined in this study can be considered unpolluted with heavy metals.

\section{REFERENCES}

BOE, (Boletin Oficial dcl Estado or Official Gazette of the State) (1991). Normas microbiôlogicas, limites de contenido en metales pesados y métodos analiticos para la determinacién 
de metales pesados para los productos de la pesca y de la agricultura (Microbio-logical standards, limits of heavy metal concentration, and analytical methods for the determination of heavy metals in fish and agricultural produce. August 2 Order. Madrid, Spain: Ed. BOE; 59375941.

Bryan, G. W. ; Langston, W. J. and Hummerstone, L. G. (1980). The use of biological indicators of heavy metal contamination in estuaries; with special reference to an assessment of the biological availability of metals in estuarine sediments from south-west Britain. Occasional Publications of the Marine Biological Association of the United Kingdom, 1: 1-73.

Bryan, G. W. ; Langston, W. J. ; Hammerstone, L. G. and Burt, G. R. (1985). A guide to the assessment of heavy metal contamination in estuaries using biological indicators. Ibid., 4: $1-92$.

Canli, M. ; Furness, R. W. (1995). Mercury and cadmium uptake from seawater and from food by the Norway lobster nephrops norvegicus. Environ. Toxicol. Chem., 14: 819-828.

CEFAS, (Centre for Environment, Fisheries and Aquaculture Science) (1997). Monitoring and surveillance of nonradioactive contaminants in the aquatic environment and activities regulating the disposal of waste at sea, 1994. Aquatic Environment Monitoring Report 47 Lowestoft, UK: Centre for Environment, Fisheries, and Agriculture Science.

Cohen, T. ; Hee, S. S. Q. and Ambrose, R. F. (2001). Trace Metals in Fish and Invertebrates of Three California Coastal Wetlands. Mar. Poll. Bull., 42: 224-232.

Davis, J. C. ; Sampson, Robert, J. (1973). Statistics and Data Analysis in Geology. Wiley, New York. 
Edwards, J. W. ; Edyvane, K. S. ; Boxall, V. A. ; Hamann, M. and Soole, K. L. (2001). Metal Levels in Seston and Marine Fish Flesh Near Industrial and Metropolitan Centres in South Australia. Mar. Poll. Bull., 42: 389-396.

EEC, (European Economic Community) (1979). Council Directive $79 / 923 / \mathrm{EEC}$ of 30 Oct. 1979 on the quality required of sheilfish waters. Luxembourg: Official Publications of the European Communities. OJ L281, 10 Nov. 1979.

El-Moselhy, K. M. I. (1993). Studies on the heavy metal level in some economic fishes in the suez Gulf. M. Sc. Thesis, Fac. Sci., Mansoura Univ. 126p.

El-Moselhy, K. M. I. (1996). Response of fish to metal pollution along the Egyptian Coast. Ph. D. Thesis, Faculty of Science, Tanta Univ. 176p.

Emara, H. I. (1982). Study of some heavy metals in Abu-Qir Bay and Lake Edku. VI es Journees Etud. Pollutions, Cannes, C.I.E.S.M.

EPA (Environmental Protection Agency) (1995). Arsenic-Freshwater Human Health Criterion for fish Consumption, USA.

Forstner, U. and Wittmann, G. T. W. (1979). Metal pollution in the aquatic environment. Springer-Verlag, Berlin, pp. 30-61.

Great Britain - Parliament. (1979). Food and drugs composition. The lead in food regulation 1979' Statutory Instrument, 1254:1-7.

Health, A. G. (1987). Water pollution and fish physiology. CRC press, Florida, $245 \mathrm{pp}$.

Hopke, P. K. (1983). An introduction to multivariate analysis of environmental data. In: Natusch, D.F.S., Hopke P. K. (Eds.). Analytical Aspects of Environmental Chemistry. Wiley, New York, 219pp. 
HEAVY METALS CONCENTRATION IN SOME FISH 163 TISSUES FROM SOUTH MEDITERRANEAN WATERS, EGYPT

Kalay M, Ay, O. and Canli, M. (1999). Heavy metal concentrations in fish tissues from the North East Mediterranean Sea. Bull. Environ. Contam. Toxicol., 63: 673-681.

Kilgour B. W. (1991). Cadmium uptake from Cadmium-spiked sediments by four fresh water invertebrates. Ibid., 47: 70-75.

Langston W. J. (1990). Toxic effects of metals of metals and the incidence of marine ecosystems. In: Furness RW, Rainbow PS, editors. Heavy metals in the marine environment. CRC press, New York 256 pp.

MAFF (Ministry of Agriculture, Fisheries and Food) (1956). Report on copper. Revised recommendations for limits for copper content of foods. Food Standards Committee. London: Her Majesty's Stationery Office.

Meglen, R. R. (1992). Examination large database: a chemometric approach using principal component analysis. Mar. Chem., 39: $217-237$.

Miao, X. S. ; Woodward, L. A.; Swenson, C. and Li, Q. X. (2001). Comparative Concentrations of Metals in Marine Species from French Frigate Shoals, North Pacific Ocean. Mar. Poll. Bull., 42: 1049-1054.

Ministry of Food, Food Standards Committee (1953). Report on zinc. London: Her Majesty's Stationery Office.

NHMRC, (National Health and Medical Research Council) (1987). National Food Standard A 12: Metals and contaminants in food. Canberra, Australia Australian Government Publishing Service.

Niazzy, Z. M. ; Abd El-Aziz, T. ; Abou El-Wafa, A. M. ; Hussain, A. A. ; Amin, T. M. (1995). Evaluation of some heavy metals in serum and muscles in Clarias Lazera in Different locations in Egypt. Bull. High Inst. Pub. Health, 25(2): 419-426.

Phillips, D. J. H. (1980). Quantitative Aquatic Biological Indicators: Their Use to Monitor Trace Metal and Organochlorine Pollution. Applied Science, London. 
Phillips, D. J. H. (1990). Use of macroalgae and invertebrates as monitors of metal levels in estuaries and coastal waters. In Heavy Metals in the Marine Environment, eds. R. W. Furness and P. S. Rainbow, pp. 81-99. CRC Press, Boca Raton, FL.

Phillips, D. J. H. and Rainbow, P. S. (1993). Biomonitoring of Trace Aquatic Contaminants. Applied Science, Barking.

Quazi, S. ; Banu, C. P. ; Rahman, M. M. ; Sayeed, S. (1995). Mineral content of fresh water and marine fish species, proceedings of the third Asia-Pasific food analysis Network Conference on Food Analysis., P. 2 (IRRI Call no. TX511C65).

Rainbow, P. S. (1995). Biomonitoring of heavy metal availability in the marine environment. Mar. Poll. Bull., 31: 183-192.

Roesijadi, G. ; Robinson, W. E. (1994). Metal regulation in aquatic animals: Mechanism of uptake, accumulation and release. In: Malins DC, Ostrander GK, editors. Aquatic toxicology (Molecular, biochemical and cellular perspectives), Lewis Publishers, London, $539 \mathrm{pp}$.

Saad, M. A. H. ; Ezzat, A.; El-Rayis, O. A. ; Hafez, H. A. (1981). Occurrence and distribution of Chemical pollutants in Lake Mariut, Egypt. 2. Heavy metals. Water Air Soil Poll., 16: 401-407.

Saouter, E. ; Campbell, P. G. C. ; Ribeyre, F. ; Boudou, A. (1993). Use of partial extractions to study mercury partitioning on natural sediment particles - a cautionary note. Inter. $J$. Environ. Anal. Chem., 54: 57-68.

Shakweer, L. ; Abbas, M. ; Alsayes, A. (1993). Heavy metals content of some fishes in Lake Edku. Bull. Fac. Sci., Alex. Univ., 33 (A): 130-164.

UNEP/FAO/IAEA/IOC, (1984). Sampling of selected marine organisms and sample preparation for trace metal analysis: Reference method for marine pollution studies No. 7, Rev. 2: $19 \mathrm{p}$. 
HEAVY METALS CONCENTRATION IN SOME FISH 165 TISSUES FROM SOUTH MEDITERRANEAN WATERS, EGYPT

Usero, J. ; Gonzales-Regalado, E. ; Gracia, I. (1996). Trace metals in bivalve molluscs Chamelea gallina from the Atlantic Coast of southern Spain. Mar. Pollut. Bull., 32: 305-310.

Usero, J. ; Gonzales-Regalado, E. ; Gracia, I. (1997). Trace metals in bivalve molluscs Ruditapes decussatus and Ruditapes philippinarum from the Atlantic Coast of southern Spain Environ. Int., 23: 291-298. 


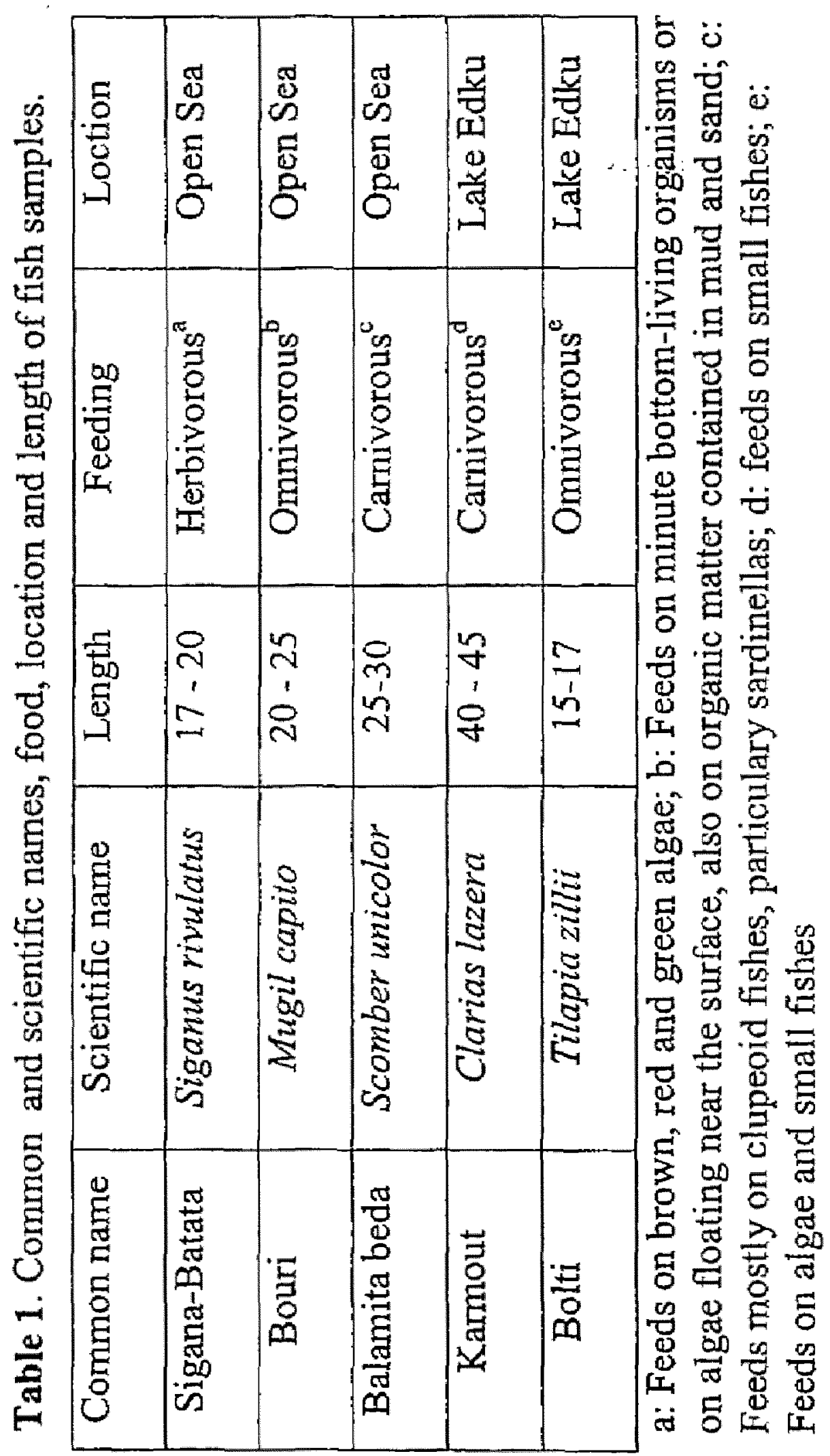




\section{HEAVY METALS CONCENTRATION IN SOME FISH \\ 167 TISSUES FROM SOUTH MEDITERRANEAN WATERS, EGYPT}

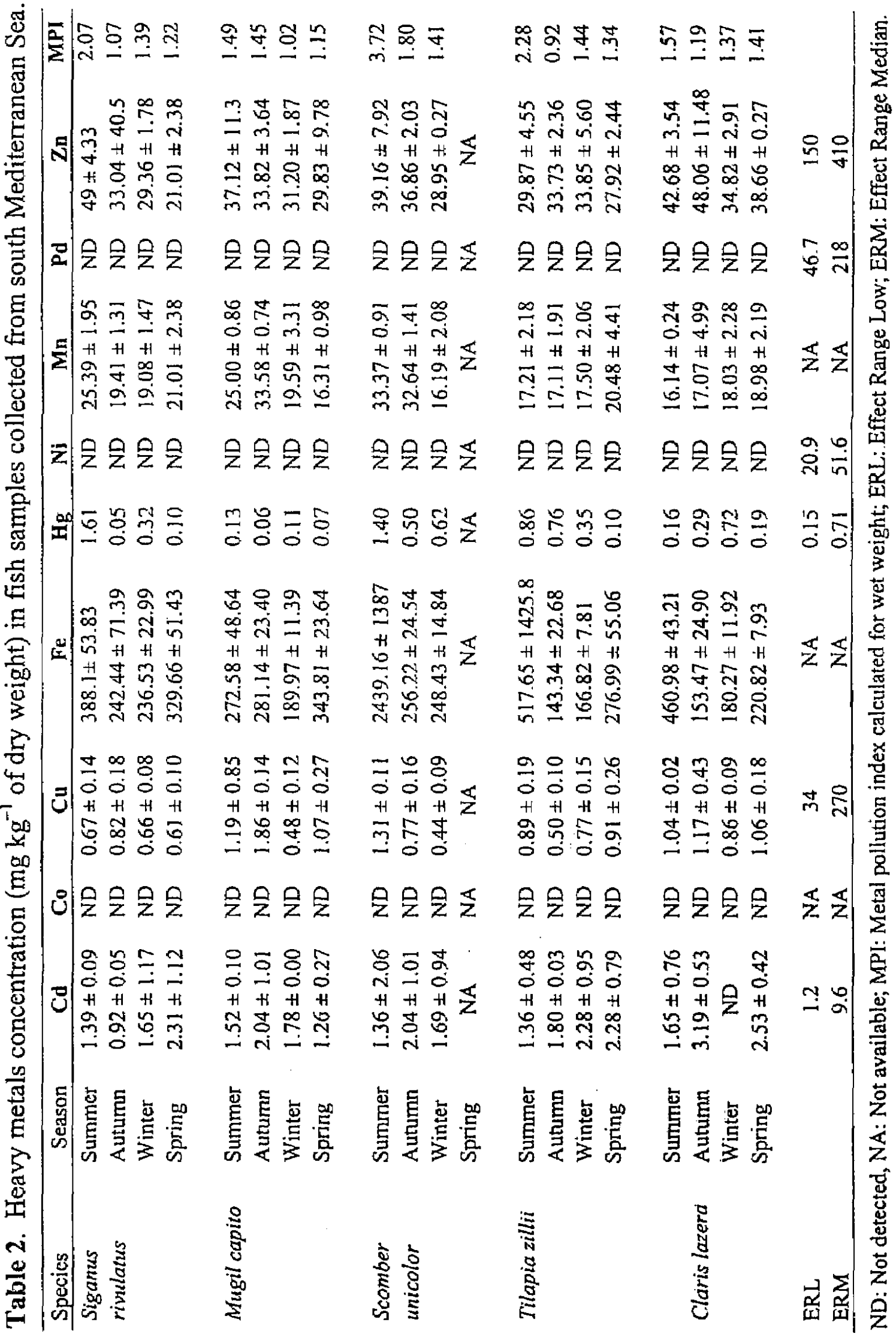




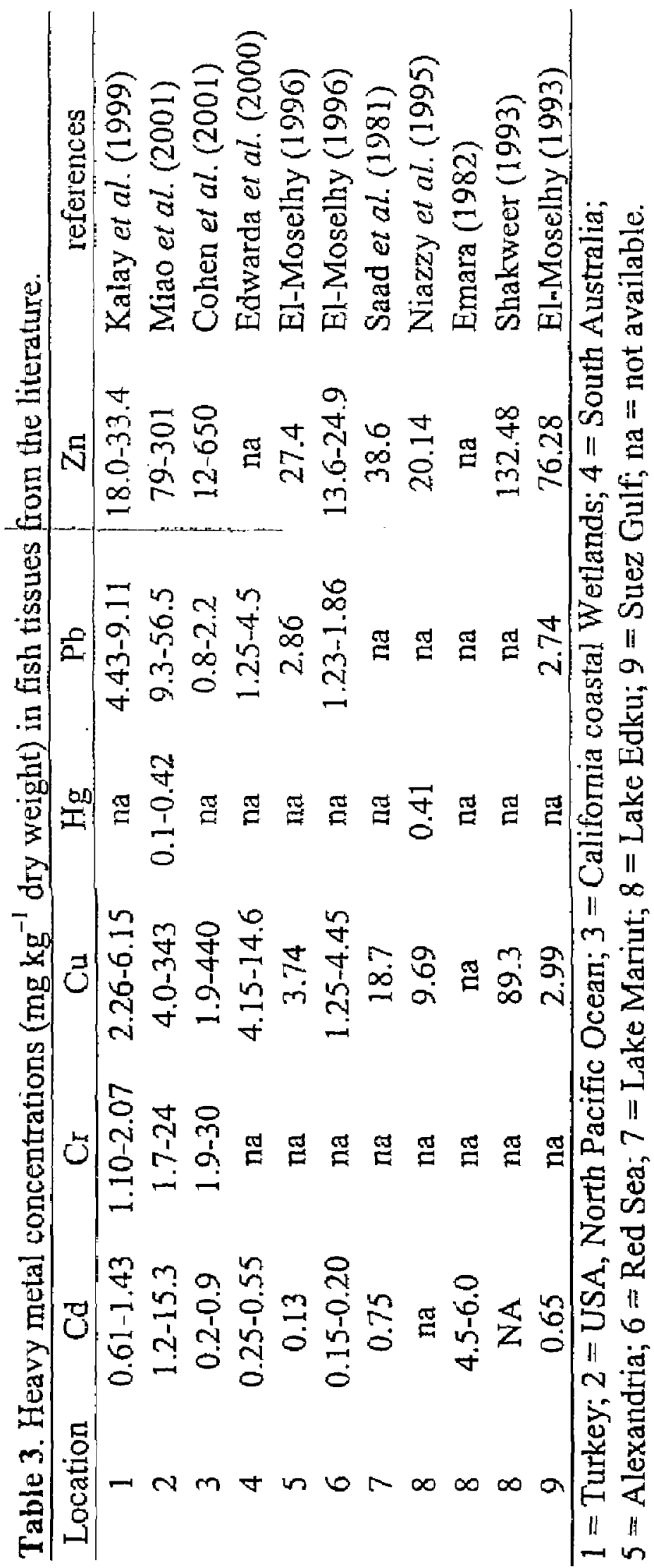


HEAVY METALS CONCENTRATION IN SOME FISH 169 TISSUES FROM SOUTH MEDTTERRANEAN WATERS, EGYPT

Table 4: Maximum acceptable limits (mg/kg) of some heavy metals

\begin{tabular}{ccl}
\hline Metal & mg/kg & Referance \\
\hline $\mathrm{Cd}$ & 0.04 & EPA $(1995)$ (safety level in fish tissue) \\
& 5 & CEFAs (1997); BOE (1991) \\
& 10 & NHMRC (1987); EEC (1979) \\
$\mathrm{Cu}$ & 100 & MAFF (1956); BOE (1991) \\
& 350 & NHWRC (1987) \\
$\mathrm{Zn}$ & 250 & Ministry of Food (1953) \\
& 750 & NHMRC (1987) \\
$\mathrm{Pb}$ & 25 & BOE (1991) \\
& 50 & Great Britain-Parliament (1979)
\end{tabular}




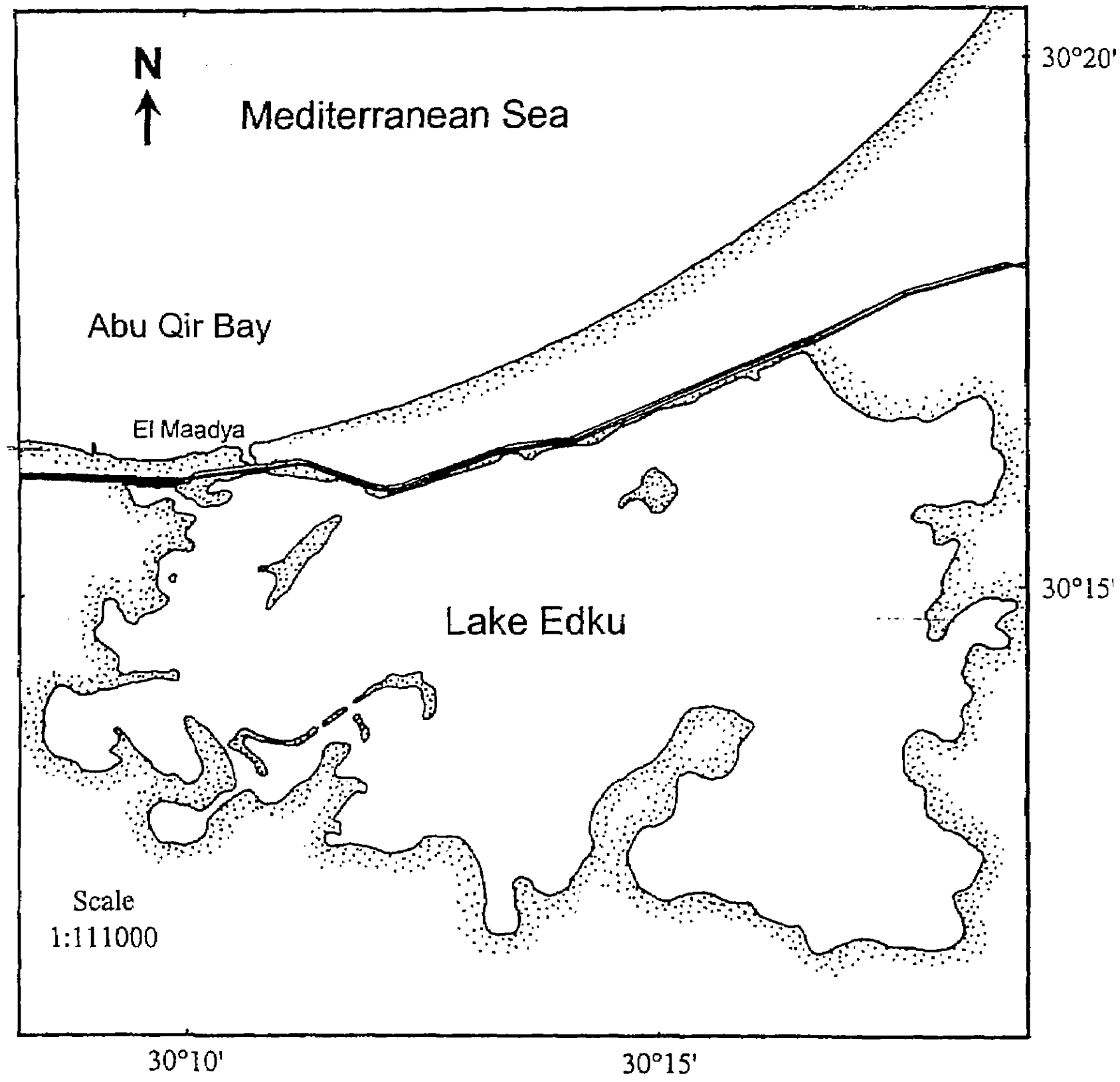

Figure 1. Map of Lake Edku and Abu Qir Bay, Egypt showing locations of study area. 


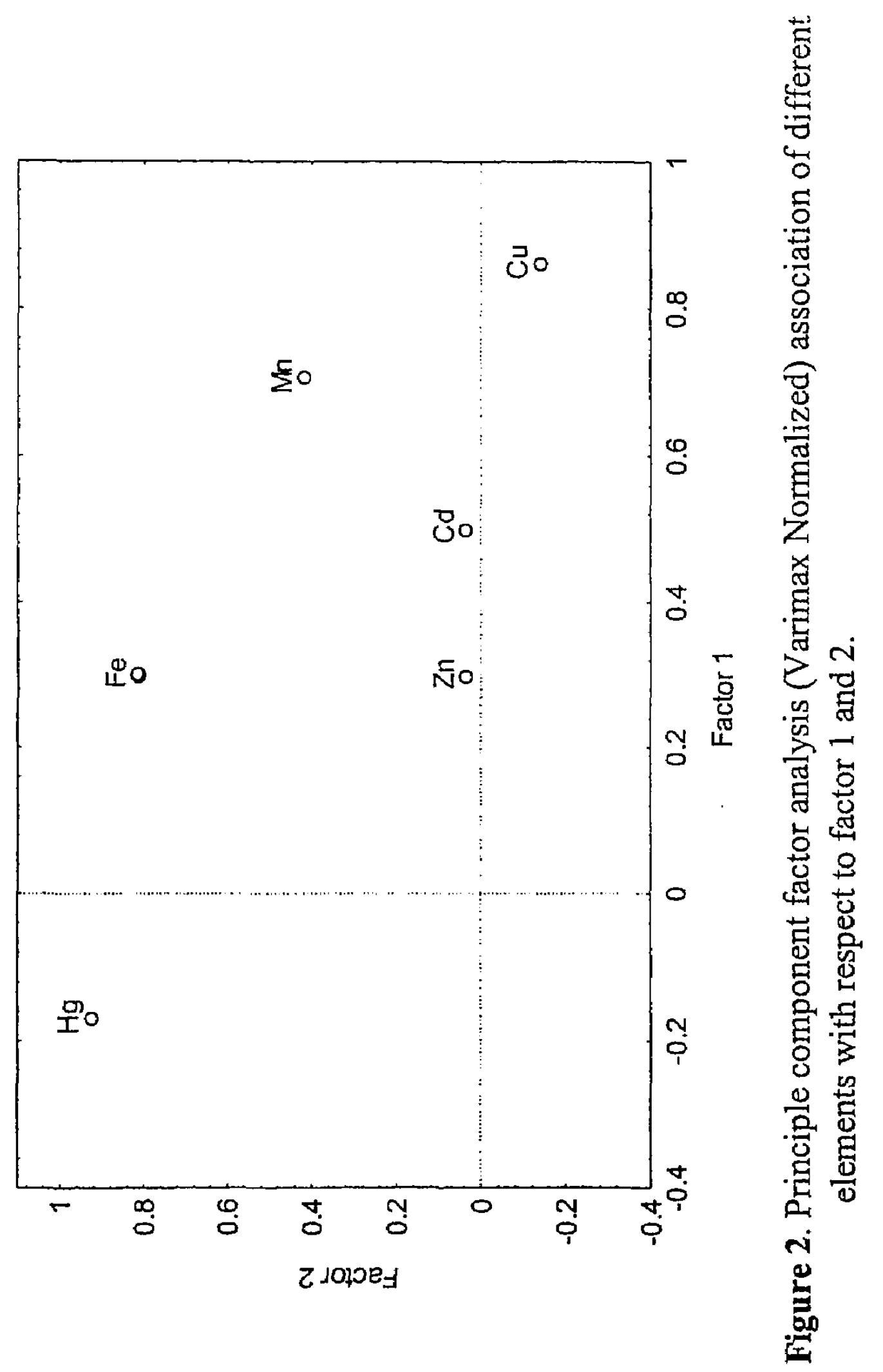

